\title{
GOETHE, EASTLAKE AND TURNER: FROM COLOUR THEORY TO ART
}

\author{
C.S. KÖNIG ${ }^{1} \&$ M.W. COLLINS ${ }^{2}$ \\ ${ }^{1}$ Institute for Bioengineering, Brunel University, UK. \\ ${ }^{2}$ School of Engineering and Design, Brunel University, UK.
}

\begin{abstract}
Wolfgang Goethe was a unique figure in the history of colour theory, being the founder of modern German literature at the same time as being a scientist. His reaction to the colour experiments of Newton was both intense and controversial. It resulted in a comprehensive exposition of colour theory especially relevant to art. As a member of the Royal Academy, the English painter Sir Charles Eastlake was sufficiently gripped by it to translate it into English. J.M.W. Turner annotated this translation and two iconic paintings resulted. Also, Turner exploited any available approaches to colour theory and this broader issue also involves Sir David Brewster and the Scottish Enlightenment. In this paper, we will give an initial study of the sequence from Goethe to Turner, together with the other issues.
\end{abstract}

Keywords: WGoethe, JMWTurner, CEastlake, DBrewster, Scottish Enlightenment, colour theory, colour polarity

\section{INTRODUCTION}

This study forms part of the wider historical connections between Newton's (1642-1727) studies on colour and Turner's (1775-1851) use of it. The men were giants in their respective fields of science and art. Newton epitomised the 'rock-like status of knowledge' [1] and of Turner 'no artist has had a more passionate interest in colour' [2]. The most prominent bridge between Newton's science and Turner's art is provided by Goethe (1749-1842). Goethe, the literary (and poet, and play writer) had even considered a career as a professional painter. As a critic and art lover, it is said that his art collection considered of a staggering 26,511 pieces, from all periods in art history by the end of his life [3]. The publication of his own extensive experiments on colour in 1810 [4] constituted 'a scathing attack on Newton' [5]. Despite this anti-Newtonianism [6], Eastlake (1793-1865) was so impressed by Goethe's work that he translated it into English in 1840 [7]. Eastlake's preface in Theory of Colours [7] is a surprisingly modern-reading justification for doing this, and moreover, he provides some 50 pages of detailed notes of archival character. Although not a scientist (some notes are by S.F., meaning 'scientific friend' [7]), Eastlake was of the highest regard in the art world, to become President of the Royal Academy in 1850 and the first Director of the National Gallery in 1855 [8].

Eastlake and Turner were very close friends [9] and Turner extensively annotated his copy of Eastlake's translation. Indeed also Lady Eastlake paid frequent tribute to Turner as an artist [10]. With self-confessed difficulty this has been analysed in detail by Gage [11]. In consistency with Turner's general attitude to art theory -'never heard him utter a single rule of colour' [12] - the notes are, for example, 'elliptical' when choosing between Goethe and Newton [11]. None the less, on Goethe's key concept of the polarity of light and darkness, Gage makes the telling comment that Turner 'was far closer (to Goethe) than he could ever have imagined' [13]. Moreover, again quoting Gage [11] it resulted in the 'purest essay in practical theory which Turner ever made' - his iconic Deluge paintings of 1843, the title of one of which includes Goethe. In keeping with this polarity, Turner's creative process could include painting 'sheet after sheet of washes, especially ochre and blue' [14].

This all lent, and lends, considerable status to Goethe's work. To Gage's [15] 'routinely included in scientific, as well as philosophical discussions of colour', and 'absorbed into the mainstream 
of ... at least the history of science' [16] should be added Bortoft's description of Goethe's current reputation among experimental psychologists and physicists [17] and Platts's very recent identification of Goethe's 'mind's eye' approach with the process of creativity in engineering design [18]. In fact, Platts's analysis was the inspiration for our current study.

In this paper, we address the overall theme described above. Also, there were other bridges between Newton and Turner, notably that of Brewster (1761-1868), a second generation figure of the Scottish Enlightenment [12]. Finally, Turner's understanding of colour was contemporary not only with further developments in optics, but also the foundations of neuroscience [19]. These aspects are also addressed.

\section{COLOUR THEORY DEVELOPMENT}

The first colour theory principles appear as early as the 15th century. To be mentioned are texts of Leone Battista Alberti dating from about 1435 (On Painting) [20] and the notebooks of Leonardo da Vinci from about 1490. However, a greater prominence of 'colour theory' begins in the 18th century, following the controversy of Isaac Newton's discovery of the spectrum. His discovery was based on his well-known experiments with prisms and light in about 1665, though even before then prisms were being used to experiment with colour. However, it was thought that somehow the prism itself coloured the light.

\subsection{Newton}

Figure 1a shows Newton's sketch of his famous experiment, the 'experimentum crucis' (crucial experiment) in which he projected the sunlight via a round hole in his shutters that was refracted through a prism. One single colour was subsequently refracted through a second prism to show that it undergoes no further change. This way he proved that a prism does not 'colour' light as was believed previously. So light was therefore shown to be composed of the colours refracted by the first prism. In another experiment, he verified that colours are components of ordinary daylight. After achieving a spectrum with his first prism, he placed another prism upside-down in the way of the

(a)

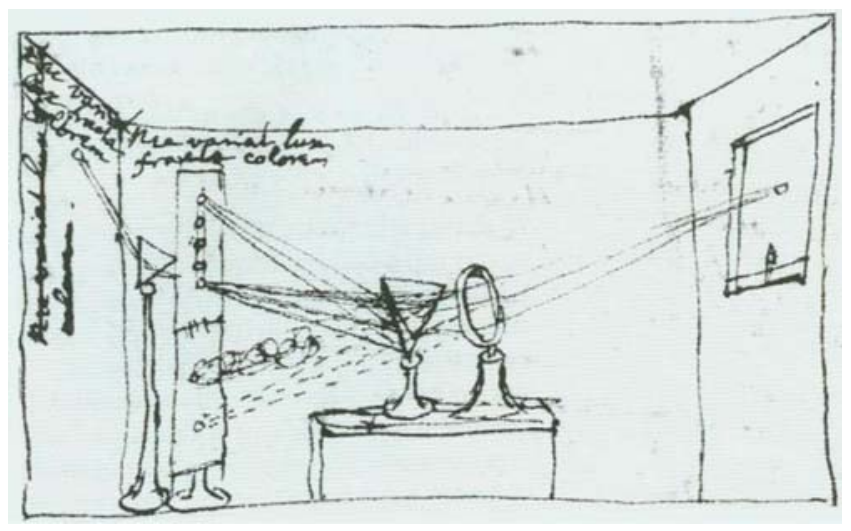

(b)

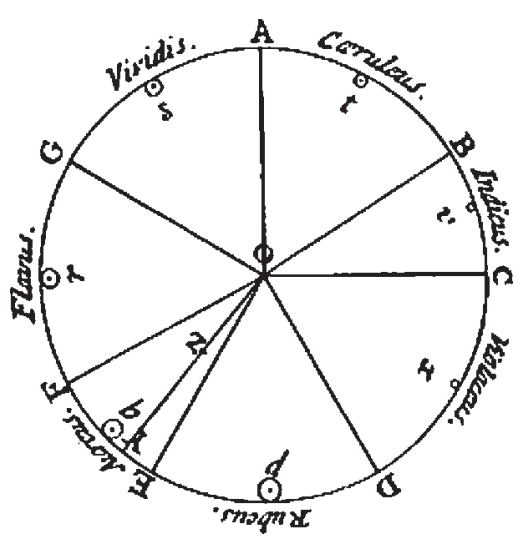

Figure 1: Newton's experiments. (a) Sketch of his experimentum crucis (crucial experiment) in which light from the sun is refracted through a prism. (b) Newton's colour music wheel. 
light spectrum after passing the first prism. The band of colours recombined into the original, white sunlight. He published his experiments by giving his public 'optical' lectures between 1670 and 1672. His paper 'Theory about Light and Colours' in the Royal Society's journal, Philosophical Transactions, was published in 1672 [21]. The first edition of his 'Theory of Colour' (Opticks) appeared in 1704 [22] in which he discussed the so-called 'primary colours'. Newton believed there were seven primary colours constituting the spectrum; red, orange, yellow, green, blue, indigo, and violet. Figure $1 \mathrm{~b}$ shows his colour music wheel in which the colours of the spectrum are shown in sequence from red to violet, as wedges between musical notes. In consistency with the analogy thinking of the Greek sophists of the classic age, he chose seven colours out of a belief that there was a connection between the colours, the musical notes, the days of the week, and the by then known planets in the solar system. Newton was also equating the physical qualities of light with those of pigments. Although he was wrong in assuming that these qualities were the same, he implied the possibility of applying certain aspects of optical theory to painting [23].

\subsection{Moses Harris}

Between 1766 and 1770, that is around one hundred years after Newton's separation of white light through a prism, a book with the title The Natural System of Colours [24] appeared, dedicated to the head of the Royal Academy at the time, Sir Joshua Reynolds. There the English entomologist and engraver Moses Harris examines Newton's work and attempts to explain the principles by which further colours can be created from three 'primary' (sometimes called 'primitive') colours based on RYB (red-yellow-blue) theory. He writes 'the principles on which are produced, materially, or by the painter's art, all the varieties if colour which can be formed from red, blue and yellow; which three GRAND or PRINCIPLE COLOURS contain all the hues and teints to be found in the different objects of nature'. His published colour chart is the first ever to appear in full hue or colour (Fig. 2a), and is the first completely symmetrical and complementary colour system [25]. His prismatic wheel contains six major colours, the three generative, red, yellow and blue, and the three mediate or secondary hues, orange, green and purple, omitting Newton's seventh colour, indigo [23]. This colour mixing behaviour had long been known to printers, dyers and painters, but these trades preferred pure pigments to primary colour mixtures, because the mixtures often turned out as too dull, i.e. as too unsaturated.

Quite soon after, in 1790, Hermann von Helmholtz and James Clerk Maxwell first discovered that the primary colours of light were in fact red, green and blue.

\section{GOETHE'S COLOUR EXPERIMENTS}

Until Goethe no one had questioned the validity of Newton's ideas on light and colour. Goethe, being both a poet and a scientist, was unique in the way the very different disciplines interacted in his achievements. Goethe's reasons for developing his own colour theory are complex, being of both rational and spiritual nature. Although he states that the painter's interest is at the heart of his investigations, his well-known antipathy against Newton's theories on colour and light may have been an equally strong motivator. Goethe's book, a 1400 page treatise, Theory of Colours ('Zur Farbenlehre') $[4,7]$ was published in 1810. It is not so much a theory, but a description of his experiments and their results. Due to his own experimental interpretations, he was misled in believing Newton to be wrong. Goethe states: 'I am the only person in this century who has the right insight into the difficult science of colours, that is, what I am rather proud of, and that is what gives me the feeling that I have outstripped many' [26]. Goethe devises colour science in a completely new way. Whereas Newton had viewed colour solely from a physical point of view, which involved light striking objects and entering 
(a)

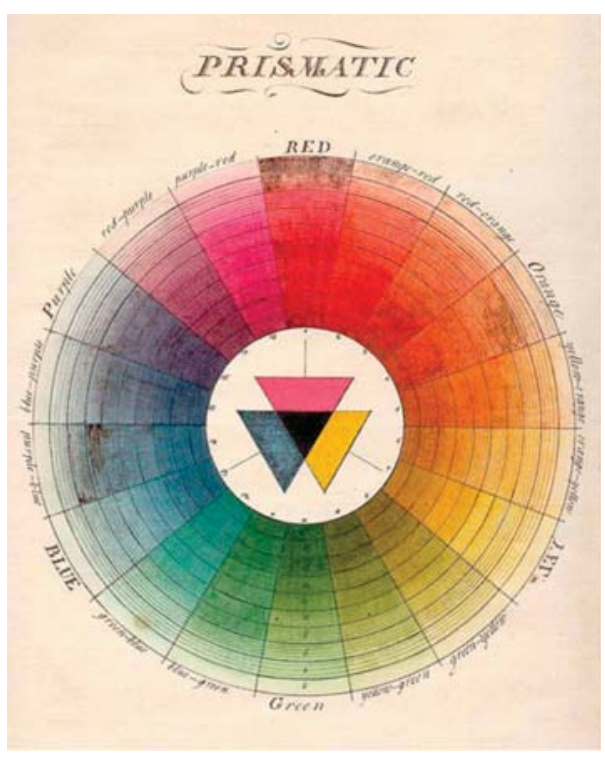

(b)

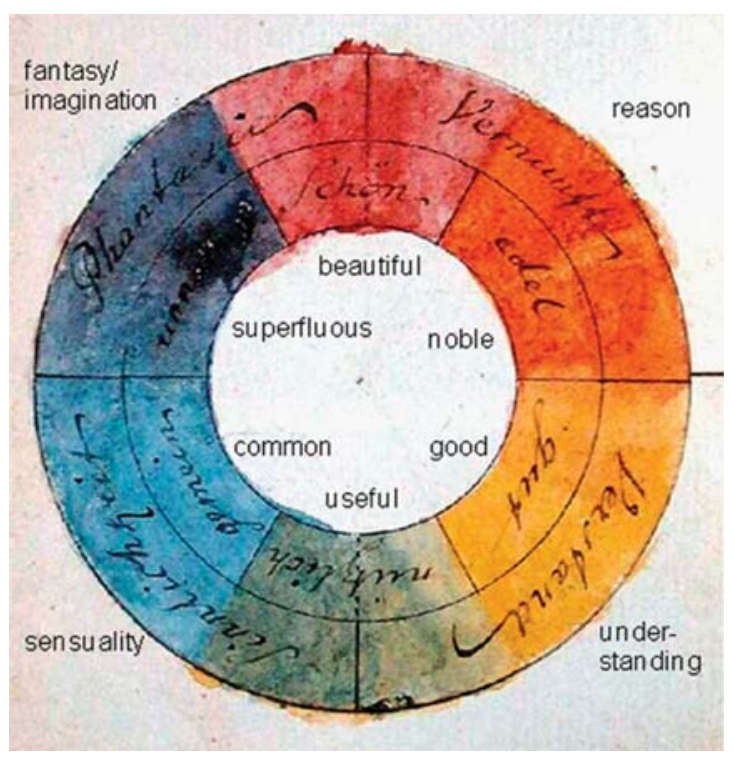

Figure 2: Colour wheels. (a) By Moses Harris. (b) Goethe's diagram of the powers of the soul.

our eyes, Goethe realises that the sensations of colour reaching the brain are also shaped by physiological aspects of colour perception [27]. In his Theory of Colours, he classifies the product of colour in three categories. The first addresses the way in which our physiology accommodates the mechanics of human vision, and then relates to the way our brains process information. The second kind concerns the physical aspects and the third, the chemical nature of colour. Therefore, according to Goethe, what we see of an object depends upon the object, the lighting and our perception. With his experiments Goethe tried to capture subjective visual phenomena in general. Goethe studied afterimages, coloured shadows and complementary colours. Whereas Newton narrowed the beam of light in order to isolate the phenomenon, Goethe observed that with a wider aperture, there was no spectrum. He saw only reddish-yellow edges and blue-cyan edges with white between them, and the spectrum arose only where these edges came close enough to overlap (Fig. 3a). For him, the spectrum could be explained by the simpler phenomena of colour arising from the interaction of light and dark edges. He writes 'yellow is a light which has been dampened by darkness, blue is a darkness weakened by the light' [7]. This agreed well with his thoughts on dualism (Fig. 4), from an introduction to his lectures on physics in Weimar in 1805 [28]. He furthermore tried to formulate laws of colour harmony and to characterise 'physiological' colours, i.e. how colours affect our mood (Fig. 2b) and studied phenomena of impaired colour perception. In the bottom of the plate in Fig. 3b, he presents how a landscape may be perceived by a person suffering from colour-blindness.

\section{TURNER'S NOTES ON GOETHE'S THEORY OF COLOURS}

As an art scholar, Charles Lock Eastlake translated Goethe's Zur Farbenlehre aiding the publicity of Goethe's 'theory' from 1840 onwards. Turner's academic friendship with Eastlake is well documented [9]. Their friendship, lasting nearly forty years, was interwoven with strands of both public and private activity, of affection and duty, and of painting and a wider conception of art [9]. 
(a)

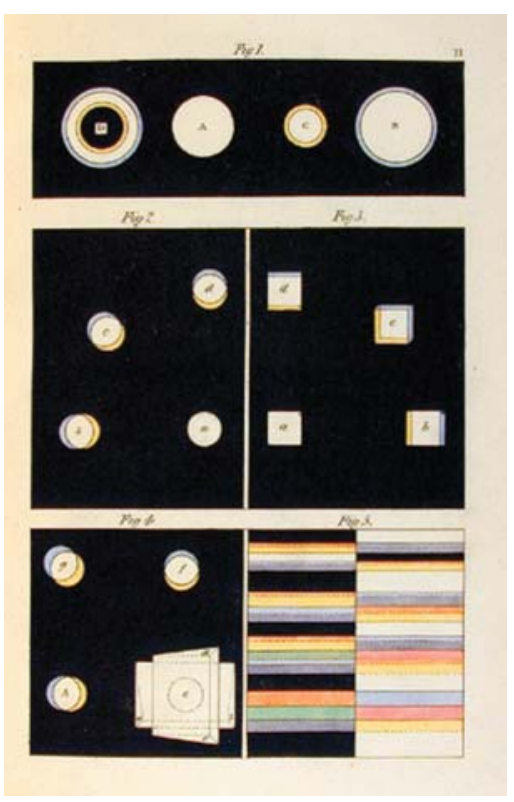

(b)

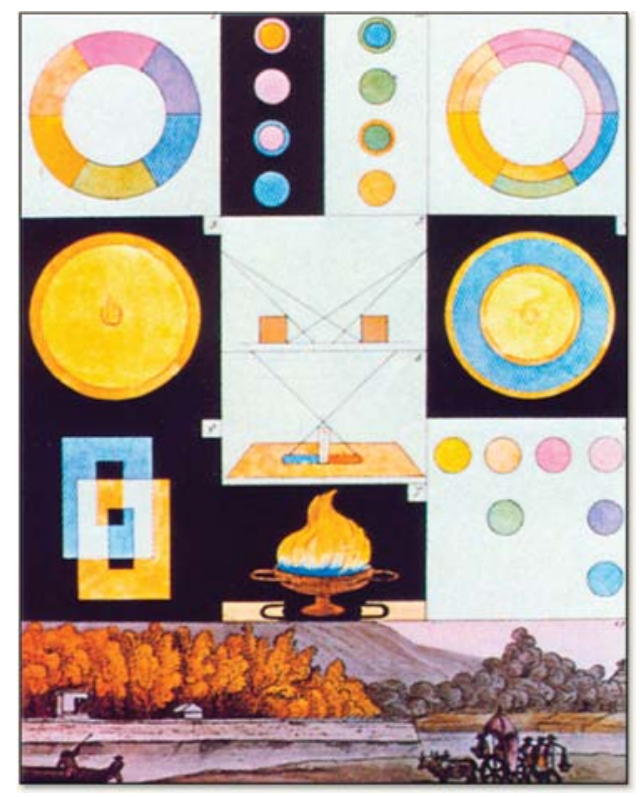

Figure 3: Goethe's experiments. (a) Experiments with aperture and spectrum. (b) His first diagram.

Therefore, it is hardly surprising that Turner would own a copy of Eastlake's translation, Goethe's Theory of Colours, which he annotated in detail [29]. From 1843 to 1847 Eastlake became Keeper of the London's National Gallery followed by directorship from 1855 until his death in 1865 . In this position, he would become responsible for the reception and initial installation of Turner's bequest [8].

Turner studied Goethe's work thoroughly and though critical of it, he readily responded to Goethe's scientific analysis of colour [30], some of it well-documented by his lectures. Indeed the lecture notes of his Perspective Lectures series suggest that Turner was well aware of Goethe's work prior to the Eastlake's translation since Turner resigned from his professorship in 1837 [29]. Undeniably Turner's interest in optics in relation to painting is manifest in his notes for the Royal Academy lecture dealing with colours. Turner visited Weimar to paint Goethe's portrait in 1819. According to Gage [29] the poet found that Turner already knew the outlines of his work as its principles were embodied in the writings of a number of British anti-Newtonians (see later). Turner noted the distinction between mathematical and 'optical', i.e. visible, colour which he tried to put right in later lectures. In a note to Goethe Turner saw this as the main barrier between science and art [11]. While Goethe had been concerned to show that the division between mathematical and 'optical' colour was an illusionary one - albeit not being fully successful - Turner maintained them as distinct [11]. What links Turner and Goethe is their common belief of polarities [29], i.e. light and dark or warm and cool colours.

\section{TURNER'S OTHER COLOUR THEORY INFLUENCES}

Full justice cannot be done to the Goethe-Eastlake-Turner theme without considering the influence of other post-Newtonian workers on Turner's use of colour theory. The principles of Goethe's work 
(a)

\begin{tabular}{|c|c|c|c|}
\hline \multicolumn{4}{|c|}{ Duality of manifestation as contrast: } \\
\hline & $\begin{array}{l}\text { we } \\
\text { light } \\
\text { body } \\
\text { mind } \\
\text { God } \\
\text { thought } \\
\text { ideals } \\
\text { sensuality } \\
\text { fantasy } \\
\text { being } \\
\text { right }\end{array}$ & $\begin{array}{c}\text { and } \\
\text { and } \\
\text { and } \\
\text { two souls, } \\
\text { and } \\
\text { and } \\
\text { and } \\
\text { and } \\
\text { and } \\
\text { and } \\
\text { and } \\
\text { two parts of a body, } \\
\text { and } \\
\text { breathing. }\end{array}$ & $\begin{array}{l}\text { the objects; } \\
\text { darkness, } \\
\text { soul, } \\
\text { material, } \\
\text { the world, } \\
\text { elaboration, } \\
\text { realities, } \\
\text { reason, } \\
\text { intellect, } \\
\text { longing, } \\
\text { left }\end{array}$ \\
\hline Physical experience: & & magnet. & \\
\hline
\end{tabular}

(b)

How Distinct Colour is

Considered in a general point of view, colour is determined towards one of two sides. It thus presents a contrast which we call polarity, and which we may fitly designate by the expressions plus and minus.

$\begin{array}{ll}\text { Plus } & \text { Minus } \\ \text { yellow } & \text { blue } \\ \text { effect } & \text { deprivation } \\ \text { light } & \text { shadow } \\ \text { brightness } & \text { darkness } \\ \text { warmth } & \text { coldness } \\ \text { proximity } & \text { distance } \\ \text { repulsion } & \text { attraction } \\ \text { affinity with acids } & \text { affinity with alkalis } \\ \end{array}$

Figure 4: Goethe's thoughts on duality. (a) From an introduction to the lectures on physics, Weimar, October 2, 1805. (b) From Theory of Colours, both from [28].

were embodied in the writings of a number of British anti-Newtonian scientists and artists like James Sowerby, Edward Bankcroft, Jospeh Reade and David Brewster which circulated among painters [29]. Here we restrict our discussion to influences of Moses Harris and Brewster on Turner's work. Space does not allow consideration of other important figures such as Field.

Newton's colour wheel with seven spectral components (Fig. 1b and [5]) was never really accepted. By contrast, Moses Harris's wheel (Fig. 2a and [5]) with its three primary and three secondary colours, constituted 'the basic form for all subsequent colour wheels' [23]. Harris's work is said to be exemplary for the level of understanding of colour order at the time [31]. Now colour was a significant feature of Turner's Royal Academy lectures on perspective, as described by Gage [13], and in 1818 he promulgated several 'colour-circles' [13]. One of these was derived from Moses Harris's wheel, but 'completely reinterpreted'. In all three yellow was the dominant primary, expressing the light partner of his light-shade interpretation of colour. 
This connects with a further key bridge between Newton, Goethe and Turner, that of the 'brilliant and highly ambitious' Scottish physicist Sir David Brewster [7,12]). He so successfully investigated aspects of the diffraction and polarisation of light, that he was internationally honoured before the age of 40 . His publishing drive was little short of awesome, with 'between three and four hundred Transactions papers' and founding Editorships of The Edinburgh Encyclopedia, The Edinburgh Philosophical Journal and the Edinburgh Journal of Science [12, 32]. Also, in contrast to this, he was the inventor (re-discoverer [32]) of the Kaleidoscope of which some 200,000 were sold as soon as it was marketed [33]. Returning to Goethe, Eastlake himself admitted that his general science was savaged by the British optical establishment, describing the response as 'somewhat vindictive' and 'unsparing criticism' [7]. Goethe was 'opposed particularly vehemently' by Brewster [8,34].

However, in two crucial aspects Brewster's convictions confirmed those of Goethe. Like Moses Harris, red-yellow-blue was primary [35], implying the good colour wheel would be sixfold (Brewster spoke of the irrationality of the spectrum) rather than Newton's seven [5]. Also, yellow was at Brewster's RYB 'apex' being, uncannily like Goethe, 'closest to the still more fundamental white light'. In Turner's 1818 lectures yellow and white were 'on a par' in his warm/cool colour ranges [33]. The overall story of Turner's Scottish visits includes the painter James Skene, a stage management partner with Sir Walter Scott for King William IV's Edinburgh visit [12]. So Turner is linked via Brewster, Skene and Scott, with the later Scottish Enlightenment $[12,36]$, and in art history terms, Gage has Turner and Brewster in considerable resonance [33].

\section{TURNER'S USE OF COLOUR IN HIS PAINTINGS}

Due to Turner's long career the colours in his paintings reflect how the manufacture of pigments changed in that time. In his early works, he used both organic pigments and mineral pigments including ochres, but he began using industrial products soon after they were introduced: cobalt blue appears in his works by 1810 , chrome yellow by 1815 and emerald green from the 1830s [37]. This in connection with his accumulated knowledge of colour science altered his use of colour, but it was also subject to other stimuli. In [23], it is noted that paintings of his in the early 1820s appear much brighter and this brighter palette was attributed directly to his trip to Italy in 1819.

In Turner's colour circle Diagram I (Fig. 5), a modification of Harris's 'prismatic' colour wheel [31], the upper and lower portions symbolise the light and dark of day and night [13]. Blue and red stand for degrees of shade, while yellow suggests light itself [37]. By using a mixture of RYB colours in pigments, he realised the destruction of the colour, tending towards 'monotony, discord and mud' [23].

Turner's pairing of paintings Shade and Darkness - the Evening of the Deluge and Light and Colour (Goethe's Theory) - the Morning after the Deluge - Moses Writing the Book of Genesis (Fig. 6) stand in direct reference to Goethe. Originally the pair was painted and framed as octagons carrying two of Turner's last and most inspired statements of the natural vortex [37]. Here, Goethe's colour polarity is evident from the light and dark or warm and cool colour oppositions along with their associated positive and negative connotations. These are clearly expressed in these terms by his usage of gold and grey [14]. In addition, Turner wanted to represent the harmonies of contrasting colours, but he adopted neither the theories of Newton nor Goethe. For Turner, their ideas followed the spectrum and primary colour frameworks too rigidly, so were unable to reflect the diversity of colours and tonal relationships in nature. Thus, he also experimented with different colour combinations [37] and in 'illustrating Goethe's point - governed by his teeming mind - used colour as a means of controlling structures of his paintings' [14]. However, it should be noted that even prior to Shade and Darkness and Light and Colour Turner produced pairings of paintings with the discussed 


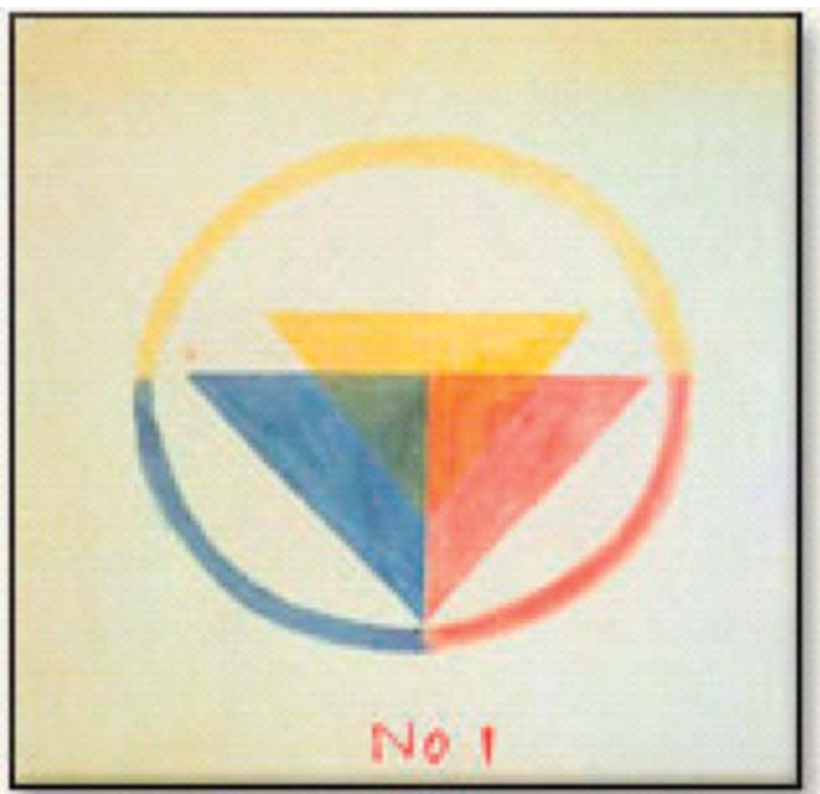

Figure 5: Turner's colour circle Diagram I.

(a)

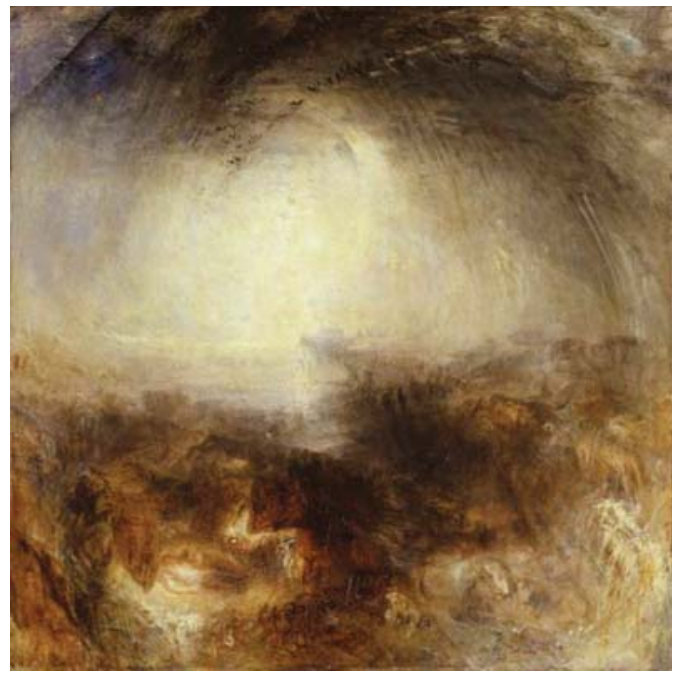

(b)

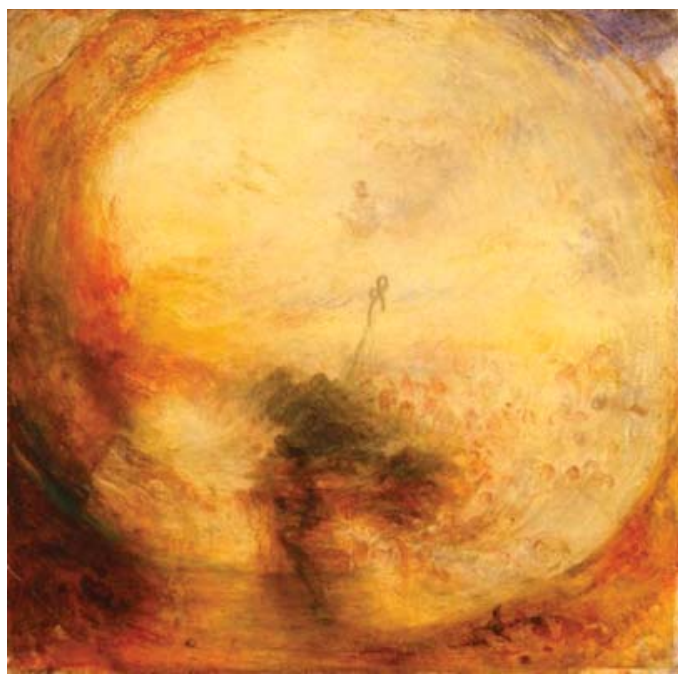

Figure 6: Turner's dedicated set of paintings exhibited in 1843. (a) Shade and Darkness - the Evening of the Deluge. (b) Light and Colour (Goethe's Theory) - the Morning after the Deluge Moses Writing the Book of Genesis. 
polarities 'before' his reading of Goethe's Theory [29], e.g. Venice and Keelmen heaving in coals by night (1834-1835). These influences jointly contributed to Turner's characteristic colour palette.

\section{CONCLUSIONS}

We can broadly conclude that Goethe's concept of the polarity of colours - the 'near white' yellow and the 'near black' blue - does indeed connect with Turner's use of colour. Further, the present-day designer's identification of colour with mood ('colour and psychology' [38]) clearly resonates with Goethe's theory. However, our initial study has shown that individual aspects require consideration in more depth. Such include:

- the different nature of the Platonism adopted by Newton [39] and that attributed to Goethe [27], and its current significance,

- the influence of Brewster and the Scottish Enlightenment on Turner's work,

- the general influence of German artists on Turner and

- the interpretation of Turner's use of colour, and hence of the cognition and perception of colour in general, in terms of neuroscience $[19,40]$.

The latter leads on, as Platts has proposed, to its significance for creativity in design.

\section{ACKNOWLEDGEMENTS}

The authors gratefully acknowledge the generous help given by the staff at the Hyman Kreitman Research Centre at Tate Britain and are appreciative of the input by Michael Leiserach towards this paper. His presentation 'The neuroscience behind J.M.W. Turner's 'translation' of colour into black and white for his engraved works' (unpublished) at 'Colour in Art, Design and Nature', Edinburgh, October 24, 2008 is acknowledged.

\section{REFERENCES}

[1] Desmond, A., Huxley: Evolution's High Priest, Michael Joseph: London, UK, p. 42, 1997.

[2] Powell, C., Turner, The Pitkin Guide, Jarrold: Andover, UK, inside cover, 2003.

[3] Marsh, J., Goethe and the visual arts: private passion and public profile. Publications of the English Goethe Society, 75(2), pp. 125-142, 2006. doi:10.1179/174962806X115299

[4] van Goethe, J.W., Zur Farbenlehre, J.G. Cotta'sche Buchhandlung: Tübingen, Germany, 1810.

[5] Cole, A., Colour, Eyewitness Art, Dorling Kindersley: London/The National Gallery of Art: Washington, DC, pp. 36-37 and p. 52, 1993.

[6] Gaunt, W., Turner (with notes by R. Hamlyn), 3rd edn, Phaidon: London, UK, p. 19 and $52,1981$.

[7] van Goethe, J.W., Theory of Colours (translated with notes by C.L. Eastlake), Dover Publications: Mineola, NY, preface and footnote on p. 197, and p. 210 and 222, 2006.

[8] Oxford Companion to J.M.W. Turner, eds E. Joll, M. Butlin \& L. Herrmann, Oxford University Press: Oxford, UK, p. 83 and pp. 127-128, 2001.

[9] Gage, J., Turner's academic friendships: C.L. Eastlake. The Burlington Magazine, 110(789), Special Issue commemorating the Bicentenary of The Royal Academy (1768-1968), pp. 676-683 and p. 685, 1968.

[10] Lady Eastlake, Journals and Correspondence, ed. C. Eastlake Smith, London, 1895.

[11] Gage, J., Turner and Goethe (Chapter 11). Colour in Turner, Studio Vista: London, UK, pp. 173-188, 1969.

[12] Hamilton, J., Turner, Random House: NY, pp. 261-262 and p. 354 and Notes K and P, 1997. 
[13] Gage, J., Colour in the perspective lectures (Chapter 6). Colour in Turner, Studio Vista: London, UK, pp. 106-117, 1969.

[14] Wilton, A., Turner and colour, in Art/Neuroscience Series in front of 'Bright Stone of Honour', Ashmolean Museum, Oxford University, 2008.

[15] Gage, J., Colour and Meaning, Thames and Hudson: London, UK, p. 169, 1999.

[16] Gage, J., Frankfurt and Weimar, Goethe and art, exhibition reviews. The Burlington Magazine, 136(1099), p. 717, 1994.

[17] Bortoft, H., Goethe's Scientific Consciousness, Monograph Series 22, Institute for Cultural Research: London, UK, p. 9 and 10, 1998.

[18] Platts, J., Newton, Goethe and the process of perception: an approach to design. Optics and Laser Tech., 38(4-6), Special Issue: colour and design in the natural and manmade worlds, eds N. Harkness, C. Greated, D. Cutler \& M. Collins, pp. 205-209, 2006.

[19] Leiserach, M. \& Whiteley, J., Movement, Colour and Perspective in J.M.W. Turner and Later Artists, Lecture List for Michaelmas Term 2006, Committee for the history of art, University of Oxford: Oxford, UK, 2006; ART + NEUROSCIENCE Seminar Series, Trinity Term 2008, St. John's College, Oxford, UK, p. 261, 2008.

[20] Alberti, L.B., On painting, 1435.

[21] Newton, I., Theory about light and colours. Philosophical Transactions, Journal of the Royal Society, 1672.

[22] Newton, I., Opticks, Theory of Colour, 1st edn, 1704.

[23] Finley, G.E., Turner: an early experiment with colour theory. Journal of the Warburg and Courtauld Institutes, 30, pp. 357-366, 1967.

[24] Harris, M., The Natural System of Colours, $\sim 1770$.

[25] Gage, J., Colour and Meaning, University of California Press: Berkley, p. 137, 1999.

[26] Webexhibits, http://www.webexhibits.org/colorart/ch.html.

[27] Duck, M.J., Newton and Goethe on colour: physical and physiological considerations, Annals of Science, 45, pp. 507-519, 1988.

[28] Matthaei, R. (ed), Goethe's Colour Theory, Studio Vista Ltd.: London, p. 68, 1971.

[29] Gage, J., Turner's annotated books: Goethe's 'Theory of Colours'. Turner Studies, 4(2), pp. 34-52, 1984.

[30] Exum, J.C. \& Moore, S.D., Biblical Studies/Cultural Studies: The Third Sheffield Colloquium, Continuum International Publishing Group, p. 306, 1998.

[31] Spillmann, W., Moses Harris's The Natural System of Colours and its later representations, Color Research and Application, 29(5), pp. 333-341, 2004. doi:10.1002/col.20041

[32] Wikipedia, items for David Brewster.

[33] Gage, J., Turner and the colour-science of his time (Chapter 7). Colour in Turner, Studio Vista: London, UK, pp. 118-127, 1969.

[34] Stephenson, H., Goethe's Conception of Knowledge and Science, Edinburgh University Press, p. 6, 1995.

[35] Brewster, D., On a new analysis of solar light. Trans. Roy. Soc. Edinb., 12, pp. 123-136, 1834.

[36] Wikipedia, items for Scottish Enlightenment.

[37] Webpages of Tate Britain, Colour \& Line - Turner's Experiments, http://www.tate.org.uk/ britain/exhibitions/turnercolourandline/.

[38] Llewelyn-Bowen, L., Design Rules, Contender Books/BBC: London, UK, pp. 67-73, 2003.

[39] White, M., Isaac Newton, Fourth Estate: London, UK, p. 56, 1998.

[40] Purves, D. \& Lotto, R.B., Why We See What We Do, Sinauer Associates Inc.: Sunderland, MA, USA, pp. 17-40, 2003. 